\title{
WHY DO UNIVERSITIES HAVE ENDOWMENTS?
}

\author{
HENRY HANSMANN*
}

\section{INTRODUCTION}

$\mathrm{T}$ HE leading private universities in the United States commonly maintain large financial reserves conventionally referred to as endowments. Harvard and Yale, for example, had endowments in 1988 of $\$ 4.2$ billion and $\$ 2.1$ billion, respectively. ${ }^{1}$ Although these two institutions are among the best endowed in the nation, there are hundreds of others that also have substantial endowments. (Table 1 gives a sample of their size and distribution.) These endowments are now so familiar that their purpose is seldom questioned. Yet, if we consider the matter closely, it is not obvious why they are accumulated.

The distinctive character of endowed institutions emerges strongly when we contrast their financial behavior with that of large business corporations. The typical business enterprise finances a substantial fraction of its capital needs through borrowing. Debt currently represents roughly one-quarter of the net worth of all companies listed on the New

* Professor of Law, Yale University. Helpful comments on earlier drafts were provided by Fischer Black, Garry Brewer, Paul DiMaggio, John Donohue, Stephen Dresch, Robert Ellickson, David Howarth, Estelle James, John Langbein, William Massy, Roderick McDougall, Peter Schuck, Richard Steinberg, James Tobin, Oliver Williamson, J. Peter Williamson, and participants in workshops at the State University of New York at Stony Brook and Yale. The Yale University Treasurer's Office gave generous assistance in interpreting the university's financial records. These individuals and organizations bear no responsibility for the views presented here.

${ }^{1}$ Figures are as of June 30,1988. Harvard also reports a figure of $\$ 4.62$ billion for the "general operating account," which comprises, in addition to funds that the university designates as endowment, other liquid assets, such as pension reserves.

Harvard and Yale are used as examples here and elsewhere in this article simply because they are among the nation's best-known and best-endowed institutions and because information on their histories and finances is relatively accessible, and not because there is reason to believe that these universities have been less thoughtful than other universities in their endowment policies; indeed, they have probably been among the most enlightened institutions in this regard.

[Journal of Legal Studies, vol. XIX (January 1990)]

(C) 1990 by The University of Chicago. All rights reserved. 0047-2530/90/1901-0009\$01.50 
TABLE 1

Distribution of a Sample of Endowment Pools by Size, 1985

\begin{tabular}{lccccr}
\hline \hline Size (in millions) & Under $\$ 25$ & $\$ 25-\$ 50$ & $\$ 50-\$ 100$ & Over $\$ 100$ & Total \\
\hline Value (in millions) & 1,417 & 1,821 & 3,210 & 26,902 & 33,350 \\
$N^{* *}$ & 120 & 53 & 45 & 66 & 284 \\
No. private & 84 & 40 & 34 & 55 & 213 \\
\hline
\end{tabular}

SourCE.-From National Association of College and University Business Officers, College and University Endowments: 1985 NACUBO Comparative Performance Study, tables 1 and 49 (1985) (hereafter cited as NACUBO). Figures are as of June 30, 1985. Data are just for institutions that responded to the NACUBO survey.

* Includes life income funds.

** Includes both public and private ("independent") colleges and universities. Public institutions are excluded in the following row labelled "number private."

York Stock Exchange, and the fraction has been larger in the past. ${ }^{2}$ Large universities, in contrast, commonly operate on capital surplus. They not only own all their physical assets outright, unencumbered by debt, ${ }^{3}$ but also accumulate large financial reserves in the form of endowment. There is nothing immutable about capital financing for universities along these lines. For example, in Japan, where private (as opposed to public) institutions account for a much larger share of higher education than they do in the United States, ${ }^{4}$ private universities are generally financed by debt. ${ }^{5}$

Published balance sheets grossly understate the value of the typical university's physical assets and thus make it difficult to compare that value with the size of the endowment. As an example, however, a very crude guess might estimate the value of Yale's physical assets at roughly

${ }^{2}$ Roger Ibbotson \& Michael Gibbs, The Corporate Bond Market: Structure and Returns (1985).

${ }^{3}$ Endowed universities do sometimes borrow: recently, for example, Harvard sold $\$ 300$ million in bonds and Yale sold $\$ 90$ million in bonds, in both cases to finance construction projects. Since the amounts involved could easily have been financed with endowment funds, such borrowing is in effect a form of tax arbitrage by which the university borrows cheaply - the bonds are tax exempt-in order to finance endowment securities whose returns to the university are also tax exempt. However, Internal Revenue Code (I.R.C.) $\S$ 145(b), added by the 1986 federal tax legislation, has now placed limits on such borrowing by restricting the total amount of nonhospital tax-exempt bonds that can be issued by an institution to $\$ 150$ million.

${ }^{4}$ As of 1986, public universities accounted for only 24 percent of college students in Japan, the other 76 percent being enrolled in private institutions; see Japan Statistical Yearbook 660, table 19-17 (1987). In the United States, in contrast, as of 1982, 78 percent of college students were enrolled in public institutions, and only 22 percent in private colleges and universities. See Statistical Abstract of the United States 114, table 185 (1987). On the other hand, in Japan the elite institutions are public, whereas in the U.S. they are generally-with some significant exceptions-private.

5 Estelle James, The Nonprofit Sector in Comparative Perspective, in The Nonprofit Sector: A Research Handbook 397, 406 (Walter Powell ed. 1987). 
the same magnitude as its endowment-about $\$ 2$ billion. ${ }^{6}$ By this estimate, Yale maintains net assets equal to at least twice the value of its productive capital, and the ratio is probably similar for the other leading endowed universities. Why would an organization follow such a policy?

This is the question addressed here. The principal focus will be on the financial behavior of colleges and universities, where the practice of operating with a substantial endowment is familiar and well established and where financial data are reasonably available. But the same issue arises with other types of nonprofit organizations, including private primary and secondary schools, hospitals, museums, and libraries. Much of the analysis offered here extends to these other types of institutions as well.

I shall not offer here a single, simple theory to explain the accumulation of endowments. Rather, I shall survey a number of possible theories and explore their strengths and weaknesses. One motive for this inquiry is simply to add to our positive theories of institutional form and behavior. Another equally important motive is to provide some normative guidance. Nonprofit institutions rarely voice any coherent policy for determining the size of their endowments; further public discussion may help the managers of these institutions take a more thoughtful approach to the

\footnotetext{
6 The balance sheet in Yale's annual financial report lists, among physical assets, a value only for the university's land, buildings, and equipment, which is given as $\$ 711$ million as of June 30, 1988. This figure largely reflects historical cost (though without provision for depreciation) and thus may be a serious underestimate of current market value. Other assets, such as the university's extensive art, rare book, and coin collections, are omitted from the balance sheet entirely, and indeed the university itself apparently has never sought to establish a current value for most of these assets. Consequently, the estimate for total physical assets offered here is no better than a wild guess. Nor is Yale in any way unique in this respect; the value of physical assets is just as obscure at Harvard and many other leading universities.

Any valuation of a university's physical assets must, of course, be highly problematic. A university's physical plant is typically highly specialized and may have much lower value in alternative uses. Consequently, values are likely to differ widely depending on whether they are based on historical cost, replacement cost, resale value on liquidation of the university, or productivity in their current use.

It is interesting that universities are so shy about disclosing the value of those physical assets that are relatively easy to value, such as art and rare books, while they are generally quite public about the value of their endowments. Several possible reasons to avoid such disclosure come to mind. First, it might incite stronger efforts to subject the universities to local property taxation or to extract payments from them in lieu of such taxes. Second, it might encourage theft. Third, it might create the impression among some prospective donors, or among government policymakers, that the universities already have sufficient wealth.

It is even more interesting that universities such as Yale do not appraise such assets even for purposes of internal decision making. Perhaps the most principled reasons for avoiding such valuation are that it would be costly, that it would not be of great benefit since the assets in question are rarely traded, and that simply having current market values in hand for such assets would give those values excessive salience in the institution's decision making. On the other hand, ignorance obviously has its costs.
} 
issue. More careful examination of the rationale for endowments may also provide important guidance to donors in deciding whether they should require that their gifts be added to endowment.

Similarly, closer analysis of the role of endowments can help provide the necessary underpinning for public policy. For example, federal tax law currently discourages the accumulation of funds by private foundations by mandating that they spend annually an amount equal to at least 5 percent of their current investment asset value. ${ }^{7}$ In 1977, the Filer Commission proposed that a similar rule be extended to all endowed nonprofits, including universities. ${ }^{8}$ Germany has already adopted such a policy. Until recently, endowed institutions in Germany had to pay out or spend their total income each year, including all endowment income other than capital gains and all gift income not specifically designated for endowment. The rule was relaxed somewhat in 1985 to permit up to 25 percent of investment income to be added to capital. ${ }^{9}$

Canada, too, has taken steps to limit endowment accumulation. In 1976, Canada passed legislation requiring that charitable organizations ${ }^{10}$ spend annually at least 80 percent of the tax-deductible donations they receive. ${ }^{11}$ The 80 percent figure was chosen on the assumption that 20 percent is a good estimate of reasonable expenses for fund-raising efforts. Consequently, this amounted to a requirement that 100 percent of gifts be spent currently. Since the rule initially applied to all gifts, it not only prevented charities from accumulating unrestricted gift income, but it also limited their ability to accept gifts restricted for use as endowment. In 1983, the Canadian Department of Finance proposed amendments under which gifts restricted to endowment would be exempted from the 80percent spending rule, but a new rule would be imposed requiring charitable organizations to spend annually at least 4.5 percent of the value of their investment assets. ${ }^{12}$ Ultimately, only the first of these proposals was enacted ${ }^{13}$ so that Canada now effectively permits the accumulation of restricted, but not unrestricted, gift income.

${ }^{7}$ I.R.C. § 4942(e)(1).

${ }^{8}$ Commission on Private Philanthropy and Public Needs (the Filer Commission), Research Papers 28-30 (1977).

${ }^{9}$ Werner Seifart, Handbuch des Stiftungsrechts 187-89 (1987).

10 Canadian tax law distinguishes between "charitable organizations," which are operating nonprofits such as universities and hospitals, and "charitable foundations," which are very much like U.S. foundations. The discussion here applies only to the former.

"Income Tax Act $\$ 149.1(2)(b)$.

12 Canadian Department of Finance, Charities and the Canadian Tax System: A Discussion Paper 2-4 (1983).

${ }^{13}$ That is, for operating charities. Charitable foundations were subjected to the 4.5 percent spending rule. 
At present, no such explicit restrictions on endowment accumulation by universities and other operating nonprofits are actively on the legislative agenda in the United States. Nonetheless, there is a serious proposal now before Congress ${ }^{14}$ for applying a 5 percent excise tax on the net investment income of all tax-exempt organizations, including endowed universities. ${ }^{15}$

If we are to assess such policy measures intelligently, we must first understand the purposes that are served by endowment accumulation. This is also true for laws governing the enforceability of donor-imposed restrictions. Anglo-American law has long forbidden, in general, the enforcement of perpetual restrictions on the use of property. An exception has been created for gifts to charity, however, and this exception has been broadly construed in recent years to cover restrictions on gifts made to nonprofit corporations, such as universities, that serve charitable purposes, even if the gift does not formally establish a charitable trust. ${ }^{16}$ Thus, a restriction on a gift to a university requiring that the principal of the gift remain intact in perpetuity - that is, that the gift be added to endowment-is today enforceable. But this exception to the law's general hostility to perpetual restraints is not unalterable and has long been controversial. ${ }^{17}$ The exception should be retained, presumably, only on a careful judgment that the purposes served by endowments are of sufficient importance to justify it.

Finally, most states provide, by statute or common law, that charities and charitable corporations (such as universities) may accumulate income, whether by the direction of a donor or at the will of the trustees,

${ }^{14}$ Staff of the Joint Committee on Taxation, Description of Possible Options to Increase Revenues (Prepared for the Committee on Ways and Means) 275-76 (June 25, 1987); Scott Jaschik, House Panel Eyes Plans to Tax Colleges on Some Income, Chronicle of Higher Education A34, November 4, 1987.

${ }^{15}$ In the United States, tax-exempt nonprofit corporations, including universities, are given special exemption from the "accumulated earnings tax" applied to other corporations by I.R.C. $\$ 531$. That tax, which is essentially a surcharge designed to discourage accumulation of earnings for purposes of sheltering them from personal income taxation, is levied on corporations that accumulate earnings "beyond the reasonable needs of the business." The fact that accumulated earnings are being held for investment, as in the form of marketable securities, rather than for the active conduct of the business, is an important criterion for determining whether the tax is applicable. See Boris Bittker \& James Eustice, Federal Income Taxation of Corporations and Shareholders 8-27 (4th ed. 1979). If the exemption from $\$ 531$ were eliminated, there would presumably be a serious question whether university endowments were subject to the tax.

${ }^{16}$ St. Joseph's Hospital v. Bennett, 281 N.Y. 115, 22 N.E. 2d 305 (1939).

${ }^{17}$ For example, Simes argued prominently in his Cooley Lectures that restrictions on the power of trustees to expend the principal of a trust not be enforceable beyond thirty years. See Lewis Simes, Public Policy and the Dead Hand (1955). 
but only to the extent that this is reasonable or necessary to the accomplishment of the institution's purposes. ${ }^{18}$ While such doctrine has apparently never been invoked to limit a university's discretion to build endowment, it nevertheless arguably provides a basis for intervention if a particular endowment accumulation appears excessive. Again, however, we need a basis for judging when endowment accumulation is reasonable or necessary to the accomplishment of a university's objectives.

At the risk of occasional confusion, positive and normative analysis will be closely intertwined throughout this essay. This is not only because the essay has the dual objectives of exploring both behavior and policy but also because of the intrinsic nature of the subject. One important reason universities accumulate endowments is presumably that their managers regard this course of action as good policy.

\section{The Discretionary Character of Endowment Saving}

When considering the behavior of endowed institutions, it is important to clarify the term "endowment" as it refers to the financial reserves of universities. That term suggests that the funds involved are entirely derived from donations. It may further give rise to the impression that the donations in question were made with the understanding that the recipient institution would hold the principal in perpetuity, using only the income for current expenditures. A substantial fraction of university endowments are not, however, subject to donor-imposed restrictions. These unrestricted funds are commonly referred to as "quasi endowment." According to a broadly based survey, as of 1985 quasi endowment constituted 34 percent of the average university's total endowment and 38 percent of the endowment funds of universities with endowments in excess of $\$ 100$ million. ${ }^{19}$ Moreover, universities can influence, through their solicitation practices, the extent to which their gift income is restricted to endowment. And, through their accounting practices and spending rules, universities can determine, within relatively broad bounds, whether income on endowed funds accumulates or is spent currently. Thus a substantial por-

18 See George Bogert, Trusts $\S 70$ (6th ed. 1987).

19 National Association of College and University Business Officers (NACUBO), College and University Endowments: 1986 NACUBO Comparative Performance Study, table 74 (1986). These figures may understate the portion of endowment funds that universities are free to spend currently. A survey undertaken in the late 1960 s indicated that 22 percent of the endowment funds that the typical college or university classified as true endowmentthat is, subject to donor-imposed restrictions that prevented the expenditure of capitalwere misclassified and, in fact, were subject to no restrictions whatever. See William Cary \& Craig Bright, The Law and the Lore of Endowment Funds 10 (1969). 
tion of endowed funds have been accumulated by institutional discretion and not donor command.

The accumulation of endowment is, in effect, a form of saving, presumably for expenditure in the future.$^{20}$ In a college or university, each dollar added to endowment represents a dollar less for current research or for educational services to current students or a dollar more in tuition that must be charged current students in order to provide them with the same level of services. The amounts thus saved will presumably be used to provide more research, more education, or lower tuition in the future. Why, then, do universities save rather than spend so much of their income?

There is surprisingly little literature on this subject. To be sure, a great deal has been written, particularly in the past two decades, on endowment policy. ${ }^{21}$ This literature, however, is confined almost exclusively to two relatively narrow questions. The first is portfolio management-that is, the types of securities and other assets in which a university's endowment funds should be invested. The second is the appropriate spending rulethat is, the amount of the annual return on the endowment that should be spent for the university's current operations, rather than accumulated. It might seem that the latter issue is necessarily tied to the broader questions of why, in general, the endowment is being maintained, how large it ought to be, and whether and how fast it should accumulate. Spending rules are rarely addressed in this broad framework, however. Rather, nearly all discussions of spending rules simply take it for granted that the rate of

${ }^{20}$ Since these institutions are nonprofit, they are constrained by the terms of their corporate charters ultimately to spend all of their income for the purposes for which they were formed. Thus a college or university presumably must, sooner or later, spend all of its income on education and research.

${ }^{21}$ See, for example, Advisory Committee on Endowment Management, Managing Educational Endowments: Report to the Ford Foundation (1969); Fischer Black, The Investment Policy Spectrum: Individuals, Endowment Funds and Pension Funds, 32 Fin. Analysts J. 23 (January/February 1976); Donaldson, Lufkin \& Jenrette, Inc. eds., Managing Endowment Capital (1969); Richard Ennis \& J. Peter Williamson, Spending Policy for Educational Endowments (1976); Robert Eisner, Endowment Income, Capital Gains and Inflation Accounting: Discussion, 64 Am. Econ. Rev. 438-41 (1974); Richard Grinold, David Hopkins, \& William E. Massy, A Model for Long-Range University Budget Planning under Uncertainty, 9 Bell J. Econ. 396 (1978); James M. Litvack, Burton G. Malkiel, \& Richard E. Quandt, A Plan for the Definition of Endowment Income, 64 Am. Econ. Rev. 433 (1974); Burton G. Malkiel \& Paul Firstenberg, Managing Risk in an Uncertain Era: An Analysis for Endowed Institutions (1976); Donald A. Nichols, The Investment Income Formula of the American Economic Association, 64 Am. Econ. Rev. 420 (1974); James Tobin, What Is Permanent Endowment Income? 64 Am. Econ. Rev. 427 (1974); J. Peter Williamson, Background Paper, in Funds for the Future (Twentieth Century Fund Task Force on College and University Endowment Policy 1975). 
spending out of endowment should not, over time, exceed the real rate of return on the investments constituting the endowment. Debate has largely been confined to narrow questions concerning the proper definition of endowment income.

I should emphasize that I am not bringing into question here the heavy reliance of universities on private donations. There are a number of reasons why these donations are necessary and appropriate for financing higher education. ${ }^{22}$ Nor do I mean to suggest that elite universities currently receive private donations in excessive amounts; indeed, the reverse is probably the case. Rather, my sole concern here is with the entirely separable question of why gift income, or any form of income, is accumulated in the form of endowment rather than being spent more or less currently.

\section{Present Spending Rules}

Most major universities today employ an endowment spending rule that calls for spending an amount roughly equal to the real rate of return on the endowment, including both cash income and capital gains. Yale is typical. By that university's calculation, the average long-run real rate of return on Yale's endowment investments has historically been roughly 4.5 percent. Consequently, Yale has adopted a policy whereby the university will annually spend from its endowment an amount equal to 4.5 percent of its current value. (To avoid large annual shifts in the amount spent as the securities markets fluctuate, Yale's spending rule actually calls for spending an amount equal to 70 percent of the amount spent in the previous year plus 30 percent of 4.5 percent of the current market value of the endowment.) This rule is designed to help assure that, over the long run, the real value of the endowment will not decrease. In fact, like other universities, Yale generally adds new funds to its endowment each year. Thus, in practice, such a spending rule tends to cause the real value of the endowment to increase over time.

For the sake of illustration, Table 2 gives figures (in constant 1967 dollars) for Yale's endowment and budget for the years 1920-85. Column

22 Owing to problems of moral hazard, and to legal restraints on involuntary servitude, students cannot borrow against their future income in amounts sufficient to finance the amount of education that is efficient for them to consume. Consequently, higher education would generally be underconsumed in the absence of adequate private or public grants. Moreover, private and public grants to educational institutions are necessary to fund the production of public goods, such as scholarly research. See Henry B. Hansmann, The Role of Nonprofit Enterprise, 89 Yale L. J. 835, 859-62 (1980); Henry Hansmann, Economic Theories of Nonprofit Organization, in Powell, ed., supra note 5, at 36. 
2 gives the value of the endowment fund; column 3 gives the amount of new income added to the endowment; column 4 gives the cash income received from endowment investments; and column 5 gives the amounts expended from the endowment. Columns 6 and 7 give, in dollar and percentage terms, respectively, the net expenditure from the endowment, computed as amounts withdrawn less new amounts added to the fund; negative figures indicate that more was added to the endowment than was withdrawn from it during the year in question. As column 7 shows, the level of net expenditure has fluctuated considerably, though in all but one of the sixty-six years covered by the table it has been well below the 4.5 percent figure that the university computes as its long-run rate of return on the endowment. ${ }^{23}$

Some universities employ an even more conservative spending policy than Yale's, spending at most only those amounts actually received as cash income from the endowment (that is, interest and dividends) and leaving capital gains to accumulate. ${ }^{24}$ Such a rule, which in practice tends to increase the real value of the endowment over time even without the addition of further funds, was the common practice among universities until the late 1960s, when more liberal spending rules like Yale's began to be adopted. Since that time, debate about endowment spending policy has focused almost exclusively on whether it is wiser to adopt one or the other of these two approaches or something in between. ${ }^{25}$

23 Many universities, Yale included, list additions to endowment as expenditures on their annual accounts, while they list transfers from endowment to the operating budget (such as endowment income that is spent annually) as income. By this means, the annual budget can (and frequently does) appear perfectly balanced even when the university's total income substantially exceeds (or falls far short of) its expenditures. For example, Yale's annual financial reports show that its annual budget balanced perfectly to the fourth significant digit in each of the years 1980-85 even though, as Table 2 shows, many millions of dollars were added to the university's endowment during each of those years (and the market value of the endowment itself increased substantially owing to a rising stock market).

It is for this reason, among others, that current university financial reports are often uninformative and indeed misleading. For a critique of current university accounting standards and some suggestions for reform, see Harold Bierman \& Thomas Hofstedt, University Accounting (Alternative Measures of Ivy League Deficits), Non-profit Report 14 (May 1973).

24 See Williamson, supra note 21.

25 As an indication of typical practice, in 1984-85, out of 203 private colleges and universities surveyed, the average institution spent an amount equal to 6.6 percent of the market value of its endowment, while the median institution spent an amount equal to 6.1 percent of market value. (These figures presumably do not reflect amounts added to endowment during the year and thus overstate the net rate of spending.) Among these institutions, 155 reported using a spending formula. At eighty-two of these institutions, the formula used was a straightforward percentage-of-market-value formula of the type used by Yale. See NACUBO, College and University Endowments: 1985 NACUBO Comparative Peformance Study 102-3 (1985). 


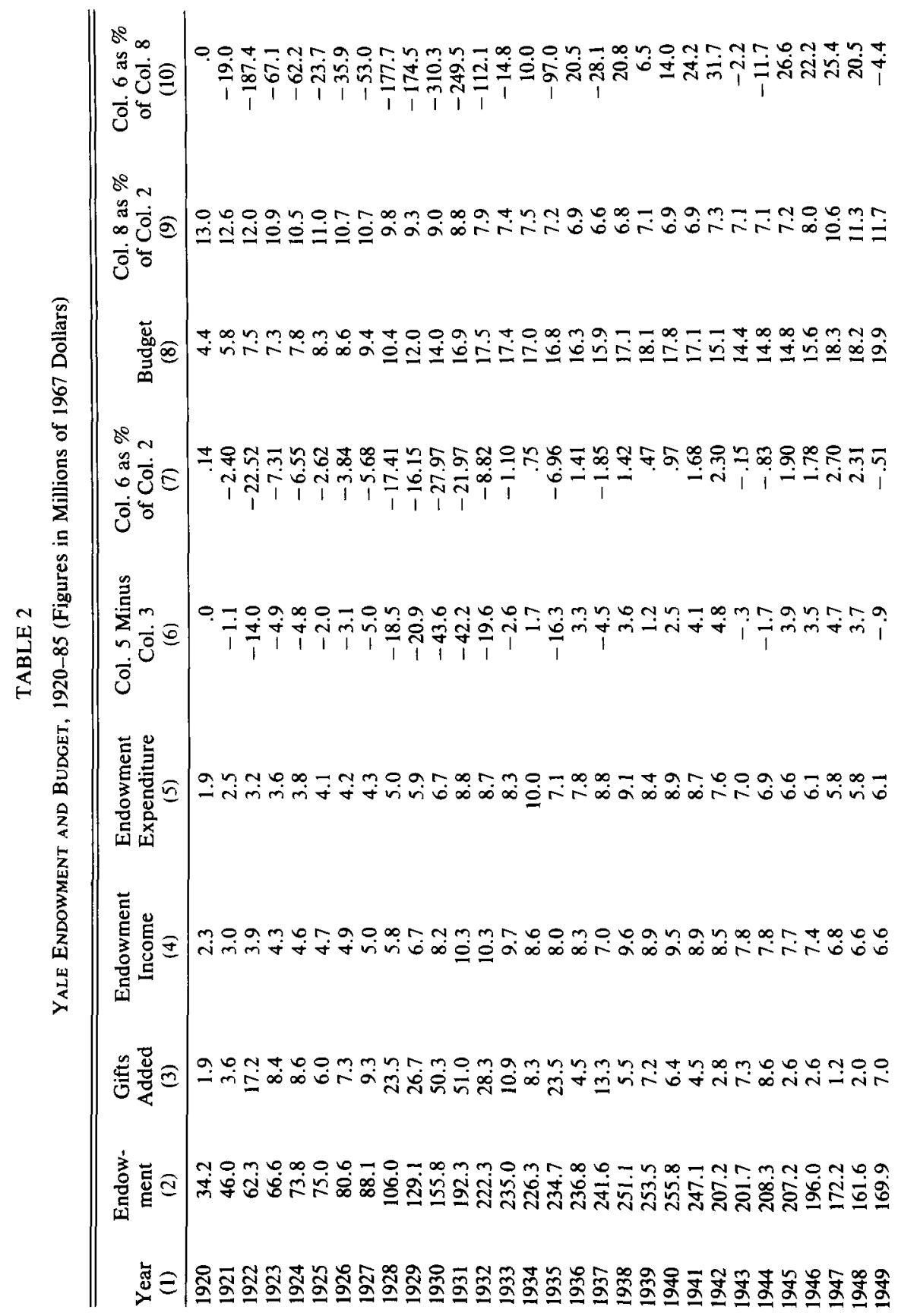




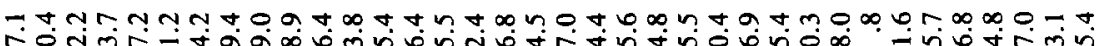

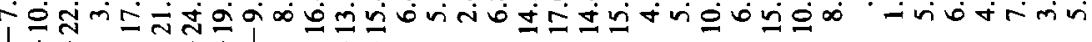
1 ।

gon

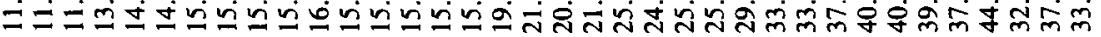

7 9 a

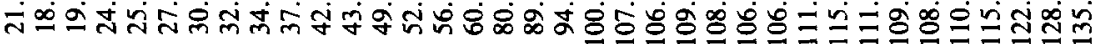

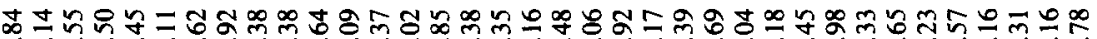
I

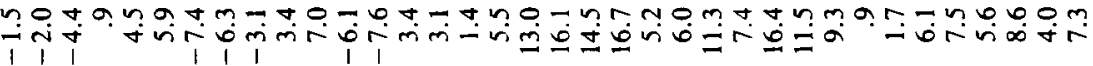

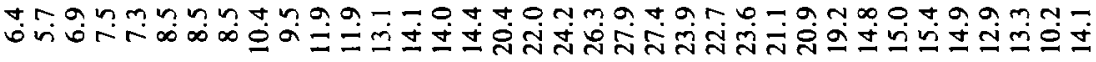
RمN

armborm, m-a NR=

의

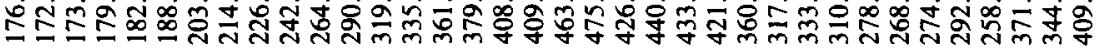

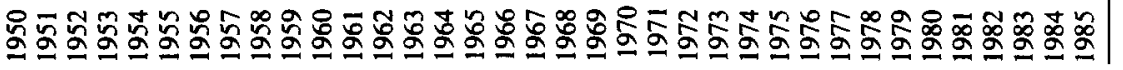




\section{INTERGENERATIONAL EQUITY}

The rare efforts to offer a principled justification for the preservation or accumulation of university endowments commonly appeal to notions of intergenerational equity. ${ }^{26}$ The following quotation from Tobin ${ }^{27}$ is among the most explicit descriptions of this rationale:

The trustees of an endowed institution are the guardians of the future against the claims of the present. Their task is to preserve equity among generations. The trustees of an endowed university ... assume the institution to be immortal. They want to know, therefore, the rate of consumption from endowment which can be sustained indefinitely. ... In formal terms, the trustees are supposed to have a zero subjective rate of time preference.

Consuming endowment income so defined means in principle that the existing endowment can continue to support the same set of activities that it is now supporting. This rule says that current consumption should not benefit from the prospects of future gifts to endowment. Sustainable consumption rises to encompass an enlarged scope of activities when, but not before, capital gifts enlarge the endowment.

Under close scrutiny, however, concerns for intergenerational equity provide very doubtful support for current endowment policies. ${ }^{28}$

\section{A. Not Equity, but Efficiency}

To begin with, the types of wealth transfers accomplished by endowment accumulation run strongly counter to prevailing notions of equity. There is every reason to believe that, over the long run, the economy will continue to grow in the future as it has in the past and that future generations of students will therefore be, on average, more prosperous than students are today, just as today's students are more prosperous than their predecessors. Thus, equity does not call for a transfer of wealth, through saving, from the present generation to later ones. On the contrary, it would seem more equitable to have future generations subsidize the present. This could be accomplished by having universities borrow, rather than save, and then repay the debt by increasing tuition in the future. To be sure, a university might reasonably choose not to incur substantial negative net worth by borrowing amounts considerably in excess of the value of its assets. Competition among universities might

${ }^{26}$ See, for example, David Hopkins \& William Massy, Planning Models for Colleges and Universities 172 (1981).

${ }^{27}$ Tobin, supra note 21 , at 427.

${ }^{28}$ Note that Tobin, in the quotation above, is offering an interpretation of the views of university trustees and does not clearly commit himself to an endorsement of the policy he describes. The perspective of trustees will be discussed in more detail below. 
prevent a university from ever raising its tuition to the point where it would run at a profit and thus pay off the debt since then students might choose to attend other (perhaps more newly founded) universities that charged tuition more in line with current costs. Consequently, feasible endowment policies may in practice be bounded on the lower end by a policy that involves, at minimum, zero net worth for the university-that is, a policy under which no net financial reserves are maintained and all assets are mortgaged to the limit of their value.

There could still be a case for transferring wealth to future generations through endowment accumulation, however, if the rate of return on endowment investments is substantially higher than the rate of growth of per capita income. In that case, the marginal gain in utility to the beneficiaries in future generations could exceed the marginal utility loss to the current generation, even though the transfer would be from the poor to the rich. This might be a desirable result if the university's objective is to maximize the undiscounted sum of its students' utilities across generations. In fact, university endowments have earned a long-run real rate of return that has averaged around 4 percent over the past sixty years, while growth in per capita real gross national product (GNP) in the United States has averaged only around 2 percent. ${ }^{29}$ In any event, this argument for endowment accumulation is based on intergenerational efficiency, not equity. In fact, it is a persuasive rationale only if the resulting efficiency gains are thought sufficient to outweigh the adverse consequences of endowment accumulation for intergenerational equity. Moreover, the intergenerational efficiency argument is itself subject to serious objections.

\section{B. Some Problems of Programming}

To begin with, maximization of welfare across generations of students by means of endowment saving and spending involves a complicated problem of programming. Even if we assume a zero rate of discount (that is, even if we give the utility of future generations of students the same weight we give the utility of the present generation in our decision making), and even if we ignore the possibility of additional future gifts to endowment, it is only in extraordinarily special cases that the correct solution to this programming problem calls for constant annual payouts

\footnotetext{
29 Yale estimates the average real rate of return on its own endowment over this period as 4.5 percent. The average rate of growth of real GNP per capita was 1.7 percent for the period 1929-85. See Economic Report of the President 254, 287 (1986).

Arguably, the correct comparison is, instead, between (1) the real rate of return on the endowment minus the annual growth rate of the student population and (2) the growth rate of per capita income. Since most universities have increased their enrollments over time, this makes the case for endowment accumulation less attractive.
} 
from existing endowment funds as suggested by Tobin. Indeed, under many reasonable models of the problem, there are no situations that justify a policy of constant annual payouts (that is, spending annually the real return on the endowment). The Appendix contains a simple mathematical illustration.

By increasing the realism of our assumptions we can identify other reasons why it is unwise for a university to engage in substantial saving even if intergenerational welfare maximization is the primary goal. To begin with, contrary to the conventional wisdom as described by Tobin above, there is no reason to ignore the prospect of future gifts to endowment in undertaking an intergenerational welfare analysis. If future gift income, like future tuition income, is reasonably foreseeable, then it should be included in any intertemporal budget plan. Ignoring it is little better than ignoring future tuition income or future faculty salaries. The larger the future gift income, the more reason to spend, not save, current gift income. (See the Appendix.)

Moreover, there is necessarily some risk associated with saving funds for expenditure in the future. While the productivity of a given university's expenditures may remain the same or increase with time, it may also decrease substantially. Demand for the university's services may fall owing to demographic shifts, increased competition from other institutions, or secular decline within the institution itself. Or, more generally, changes in educational technology may make other forms of instruction more effective. Such risk provides an additional reason to apply a positive discount rate to expenditures out of a university's endowment, even if we do not discount future utilities. ${ }^{30}$ And this throws even further doubt on an endowment policy that transfers substantial wealth from the present generation to the future.

The most sophisticated efforts at developing programming models for university financial planning, namely those of Grinold, Hopkins, and Massy, ${ }^{31}$ do not confront these issues of efficiency and equity directly because they do not (unlike the very simple model in the Appendix) seek to maximize an intergenerational welfare function that values the university's ultimate outputs (education and research, for example). Rather, in their operational form, these models focus principally on the feasibility and consistency of alternative financial goals, such as maintaining the ratio of student aid to tuition at 0.1 or maintaining the ratio of total expenses to endowment at 0.5 . Although these authors do suggest some

${ }^{30}$ This point has been made before in Eisner, supra note 21. See the Appendix for illustration.

${ }^{31}$ Grinold, Hopkins, \& Massy, supra note 21; Hopkins \& Massy, supra note 26. 
substantive goals for endowment policy, those goals are not derived from the formal models but are only briefly and unsystematically defended. In particular, they suggest a policy under which the payout from the endowment will cover a constant (or perhaps even an increasing) share of total university expenses in every future year, ${ }^{32}$ though they do not state what that share should be or how it should be determined. They justify this approach principally on the basis of the increasing real costs faced by universities, ${ }^{33}$ a consideration to which we now turn.

\section{Increasing Costs}

A common variant of the intergenerational equity argument invokes the increasing cost of education for succeeding generations. The real cost of a university education may well rise in the future, as it has in the past, since there is little increase in productivity in education relative to other goods. Thus, if the value of a university's endowment were held constant, the income from that endowment would finance an ever-decreasing fraction of the cost of education. As a consequence, it is argued, the real value of the endowment should be increased over time (by spending less currently) so that the amount of real income spent from the endowment each year will rise at a rate at least sufficient to constitute a constant fraction of the cost of education. ${ }^{34}$

If the demand for education, both now and in the future, were completely inelastic, then a higher rate of growth in costs would make the case for building an endowment stronger in terms of an intergenerational welfare calculation. ${ }^{35}$ Even then, it would by no means follow that the appropriate rule would be to maintain endowment income as a constant fraction of the cost of education. Moreover, and more important, if (as is obviously true) demand is not completely inelastic - that is, if the amount of education consumed at a university is a choice variable for consumers in terms of either quality or quantity - then countervailing efficiency considerations argue strongly against saving more when the cost of education is rising. If education in future generations will be costlier than it is at present, then there is no reason to consume less of it today in order to consume more of it in the future. This would simply be substituting a more expensive good for a cheaper one. Taxing education through endowment accumulation in the present in order to subsidize it in the future

${ }^{32}$ See Hopkins \& Massy, supra note 26, at 173, 184.

${ }^{33}$ See $i d$. at $180-84$.

34 Id.; Ennis \& Williamson, supra note 21, at 20; Williamson, supra note 21; Frederick E. Balderston, Managing Today's University 260-61 (1974).

${ }^{35}$ See the Appendix. 
only distorts consumption of education both within and across generations, leading us to consume too little of it today and too much tomorrow.

\section{Institutional Competence}

To the foregoing considerations we must add the problem of institutional competence. Even if the society's overall savings rate appears for some reason inappropriately low, there seems little reason for a university to take on itself the task of rectifying the situation. Transferring wealth from one generation to another is quite different from creating and disseminating knowledge, which is presumably a university's primary purpose and area of expertise. Moreover, the university can, in general, only transfer wealth among generations of its own students; it cannot otherwise affect the overall distribution of wealth in the society at large. While it may make sense for the national government to employ monetary and fiscal policy to change the social savings rate and to redistribute wealth across generations, such a goal is much more problematic for a private institution.

Moreover, any funds saved for intergenerational transfers could alternatively be used to promote intragenerational equity by providing greater financial aid today to indigent students. Since intragenerational equity is a much simpler and less controversial goal than intergenerational effciency, why not make it the primary focus of the redistributive efforts of universities?

\section{E. What Form of Investments?}

There is one last point. Even if a university wants to help future generations, financial investments may not be the best means to that end. Most university activities involve some form of investment for the future. The research a university undertakes today, the education it provides, the faculty it builds, and the physical facilities it constructs will all yield a return decades or even generations in the future. Accumulating funds in an endowment is worthwhile only if the return to endowment investments exceeds the return from these other activities. Or, put differently, when a university adds a dollar to its endowment for the purpose of making an intergenerational transfer, it is implicitly making the judgment that the dollar will have a higher rate of return if invested in stocks and bonds than in educating an undergraduate, or doing research in biophysics, or adding books to the library.

In sum, although intergenerational equity is the objective most commonly offered to justify university endowment policies, it is a singularly 
weak justification. If endowment accumulation is rational, then presumably it must serve some other purpose. Of course, it is possible that endowment accumulation is not rational. Even if pursuit of intergenerational equity is not a convincing argument for endowment accumulation, universities may act as though it is simply because they have not thought the issue through carefully. Consequently, the failure of this argument as a normative justification does not necessarily imply its irrelevance as a positive explanation.

\section{LUMPY Funding}

A related, but more prosaic, justification for endowment accumulation might be that donations to a university are often lumpy. Sometimes a founder or other major benefactor makes a single large donation that represents a substantial fraction of the total gift income the university can expect to receive in the near future. Similarly, economies of scale and scope in fund-raising may make it efficient to mount large campaigns for donations at substantial intervals rather than to seek to maintain a steady flow of smaller gifts. In such cases, it may be most efficient to spend the income over a period of years, rather than immediately on receipt, and thus keep the university's annual expenditures on a reasonably stable path. This concern at least provides a justification for holding and investing funds over moderate periods of time-long enough to smooth out expenditures. But the argument does not generally provide a justification for holding funds as permanent endowment, and it does not apply at all to the numerous small gifts that, in the aggregate, have a value that is relatively constant and predictable from year to year.

These considerations of lumpy income, moreover, probably offered a much stronger rationale for holding funds as endowment in the nineteenth and early twentieth centuries than they do today. In those earlier times, universities more commonly received very large personal bequests and did not engage in fund-raising on as continuous a basis as is common today ${ }^{36}$ More particularly, these considerations do not justify the common contemporary practice of regularly diverting a portion of general unrestricted gift income to the endowment.

\footnotetext{
${ }^{36}$ The figures for Yale's endowment in Table 2 reflect this fact. The huge increase in the size of Yale's endowment in the 1920s and 1930s was in large part the result of gifts from just two important donors (Sterling and Harkness) and a single fund-raising campaign in 1926-27 (the pledges from which were paid in over the following years). See George Pierson, Yale: The University College 1921-1937 (1955); Brooks Kelly, Yale: A History (1974).
} 


\section{Tax InCEntives}

Nonprofit universities are exempt from the corporate income tax. As a consequence, their return on invested capital is higher than the return to taxable personal or corporate investments.

There are two ways in which this exemption might affect a university's savings policy. The first, and most obvious, is by altering the university's trade-off between the costs of present and future production. The second is by encouraging explicit or implicit contracts between the university and potential donors.

To understand the latter incentive, suppose, for example, that a given graduate wishes to bequeath a certain amount to her alma mater when she dies. Putting aside questions of risk bearing, it would then be advantageous for her instead to contribute now an amount equal to the present value (at the after-tax interest rates available to her) of the amount of the bequest she plans to make, on the condition that the university not spend the gift currently but, rather, invest it and accumulate the returns and then spend the entire accumulated amount on her death. This strategy will yield a greater benefit to the university at no increase in cost to the donor since the university can invest the funds at a higher after-tax rate than she can. Some portion of a university's general endowment accumulation might be seen as part of an implicit contract of this sort.

These tax incentives may well have contributed to the tendency of universities to accumulate endowments. There are, however, several reasons to believe that tax considerations alone cannot explain endowment accumulation.

First, business corporations are entitled to deduct 80 percent of intercorporate dividends when computing their corporate income tax, and this eliminates some of the disparity between universities and business corporations in the returns to investing in stocks. ${ }^{37}$

Second, since the tax exemption increases wealth for the university in every year, it has an income effect that may offset the increased incentive for saving that comes from the substitution effect of a higher rate of return: less money need be set aside currently in order to provide a given amount of income in the future. Thus, the mere fact that the return to

37 I.R.C. $\$ 243$. The benefits of this provision are to some extent limited by I.R.C. $\$ 531$, which imposes an "accumulated earnings tax" on accumulations of earnings beyond the reasonable needs of the business. See note 15 supra. Whether the latter tax, which is mostly applied to closely held firms, would be applied to a publicly held corporation that built up substantial reserves is unclear. See Bittker \& Eustice, supra note 15, at 8-6 to 8-8 (4th ed. 1979). 
savings is higher than it would otherwise be for a university does not necessarily mean that the university will-or should-save more. To determine this, one must know the university's objective function-that is, what it is saving for.

Third, as a historical point, universities such as Harvard and Yale began accumulating substantial endowments by the middle of the nineteenth century, long before either the corporate or the personal income tax was in effect.

Of course, just because the tax exemption for endowment income does not appear to have been the principle motivation for endowment accumulation does not mean that the exemption has not had an effect at the margin on the size of university endowments. Nor does it mean that it good policy to continue to exempt endowment income from taxation. If universities have a tendency to accumulate inefficiently large endowments, then a tax regime less favorable to endowment accumulation may be appropriate.

\section{Maintaining Liquidity}

Another possible reason for maintaining a large endowment is to have a reserve against financial reversals. Income may fall suddenly for various reasons: the number of qualified admissions applicants who can afford full tuition may drop because of demographic changes or economic recession; private contributions may decline because of a change in the tax laws or an unfavorable reaction by the alumni to the institution's policies; federal grants for education and research may be cut after a change in administrations. Expenses may also rise dramatically; the energy shock of the early 1970 s is just one obvious example. With a substantial accumulated surplus in hand, these financial reversals can be ridden out with a minimum amount of internal disruption.

\section{A. Are Universities Particularly Vulnerable to Financial Shocks?}

To be sure, financial reversals affect business firms as well. Yet business firms generally do not maintain large financial reserves as a consequence. If the need for liquidity explains endowment accumulation, therefore, it must be because nonprofit educational institutions are much more vulnerable to temporary financial shocks than ordinary business firms. This could, however, be the case. For one thing, a university may be much less able than a business firm to rely on borrowing as a means of riding out hard times since a university's assets are usually highly organization specific and thus provide poor collateral. Moreover, a business 
firm can, in extremis, seek new equity capital when its current financial situation is tight but its future holds out hope. A nonprofit firm, in contrast, does not have the option of selling equity. Finally, educational institutions have only limited flexibility in adjusting their scale of operations on a short-term basis. A large proportion of faculty have lifetime tenure, and thus they, and the other personnel that support them, cannot simply be laid off when finances are tight. Students, in turn, are admitted for degree programs that typically last four years and must be serviced for that period.

\section{B. How Much Security Do Endowments Provide?}

Existing endowments at many universities are large enough to serve as substantial financial buffers. Of a sample of 206 of the nation's betterendowed private colleges (a subset of those included in Table 1), the average institution had an endowment twice as large as its current operating budget, and four institutions had endowments more than 7.5 times as large as their current budgets. ${ }^{38}$ To illustrate the amount of security that such endowments might provide, let us again take Yale as an example and ask about the consequences of a total cutoff of federal government funding. At present, direct and indirect federal government support to Yale (in the form of grants, contracts, and student aid) is roughly one-quarter of the university's operating budget. (See Table 3.) Yale's endowment, which in 1986 was 4.4 times the size of its budget, could serve as a complete substitute for this support, thus keeping the size of the total budget unaffected by a cutoff of federal funds, for a period of twenty years before the endowment would be completely depleted. ${ }^{39}$ Even at the end of this twenty years, the university would still retain all of its physical assets, with their value unaffected and presumably available, at least in part, as security for loans to carry the university through yet further periods of adversity. Alternatively, if we assume that only the unrestricted portion of the endowment is available to be spent, then Yale could operate for about eight years before it would have to cut back the programs that were previously funded by government or find other sources of support for those programs.

38 NACUBO, 1986, supra note 19, at 94.

39 This computation assumes that, over the twenty years, the endowment will be drawn on not only to make up the 25 percent of the budget that would otherwise come from federal funds but also to provide the 8.3 percent of the budget that has, on net, been drawn from the endowment annually on average over the past twenty years (which is the average of col. 10 of Table 2 for the period 1966-85). Thus, endowment would be drawn on for a total of onethird of the budget annually. 
TABLE 3

Relationship of Endowment to Nongovernmental Budget at Yale, 1964-85

\begin{tabular}{cccc}
\hline \hline Year & $\begin{array}{c}\text { Government Income } \\
\text { as \% of Budget } \\
(1)\end{array}$ & $\begin{array}{c}\text { Non- } \\
\text { governmental } \\
\text { Budget* } \\
(2)\end{array}$ & $\begin{array}{c}\text { Col. } 3 \\
\text { as \% of } \\
\text { Endowment } \\
(4)\end{array}$ \\
\hline 1964 & 32.7 & 37.8 & 10.5 \\
1965 & 33.4 & 40.2 & 10.6 \\
1966 & 34.7 & 52.5 & 12.9 \\
1967 & 36.6 & 56.5 & 13.8 \\
1968 & 37.8 & 59.0 & 12.7 \\
1969 & 36.3 & 64.2 & 13.5 \\
1970 & 32.8 & 72.1 & 16.9 \\
1971 & 29.8 & 74.9 & 17.0 \\
1972 & 30.0 & 76.3 & 17.6 \\
1973 & 30.1 & 76.1 & 18.0 \\
1974 & 27.3 & 77.5 & 21.5 \\
1975 & 26.2 & 78.5 & 24.7 \\
1976 & 25.1 & 83.5 & 25.0 \\
1977 & 24.9 & 86.6 & 27.9 \\
1978 & 25.9 & 82.9 & 29.7 \\
1979 & 24.9 & 82.3 & 30.6 \\
1980 & 24.9 & 81.1 & 29.6 \\
1981 & 30.8 & 76.2 & 26.0 \\
1982 & 28.9 & 82.3 & 31.9 \\
1983 & 27.6 & 88.6 & 23.8 \\
1984 & 26.1 & 94.9 & 27.6 \\
1985 & 26.3 & 99.4 & 24.3 \\
\hline
\end{tabular}

* Figures in millions of 1967 dollars.

\section{Some Inconsistencies}

There are, however, good reasons to doubt that most universities have accumulated endowments principally for smoothing out annual income flows or sustaining liquidity during periods of temporary financial stringency.

For one thing, the major source of cost inflexibility that most distinguishes universities from for-profit firms and from other types of nonprofits-namely, academic tenure-developed only in the twentieth century. Yet endowments played a more important role in the finances of universities in the nineteenth century than they do now. In addition, it is generally recognized that financial distress may be justification for abrogation of tenure.

Moreover, the spending rules currently popular among universities, which call for spending a given fraction of the real value of the endowment annually, are directly inconsistent with a policy of using the endow- 
ment as a financial buffer. Such a rule commits an institution to using its operating budget as a buffer to absorb shocks to the market value of its endowment, rather than vice versa. The same conclusion holds for the spending rules of earlier decades, which spent annually only cash income and not capital gains.

To be sure, current spending rules may be simply fair-weather expedients, to be adhered to only so long as times are flush. In fact, universities that currently employ such rules have in recent years commonly been adding new funds to their endowments each year, so that the nominal spending rule overstates the rate of endowment spending. For most universities, the present is therefore actually a time of endowment accumulation. When times get more difficult, the new additions to endowment will likely be reduced or eliminated, hence effectively increasing the spending rate. And if a crisis comes, universities may be prepared to abandon their spending rules altogether and actually reduce their endowments.

Has this, in fact, been the long-term behavioral pattern for most universities? It is not easy to tell. Reliable and consistent historical data on university finances are not readily available. Moreover, a variety of complications make the historical record difficult to interpret.

Yale's experience in recent decades offers an illustration. From column 7 of Table 2 we see that there have been years, principally in the 1920s and 1930s, in which substantial amounts have been added to the endowment on net. There have not, however, been any corresponding periods of substantial dissaving. In only one year, 1975, did the net spending rate exceed the figure of 4.5 percent that the university estimates as the longrun rate of return on its endowment, and only in two years did it exceed 3.5 percent. This pattern seems inconsistent with the hypothesis that the endowment has been used as a financial buffer.

In particular, Yale did not withdraw substantial funds from its endowment to help it through the financial crisis of the 1970s. During that decade Yale, like most universities, found itself suddenly in straitened circumstances: private demand declined, government support abruptly stopped its former upward trajectory, and energy costs increased dramatically. These difficulties are reflected in the budget figures in column 8 of Table 2: after two decades of substantial and uninterrupted growth, Yale's budget remained roughly constant in real terms from 1970 to 1980 , in spite of increases in the real costs of some important inputs, such as energy. These circumstances would seem to call for drawing on endowment. Yet the average net endowment spending rate from 1971-80 was only 2.21 percent-slightly higher than the average rate of 1.28 percent from 1961- 
70 , roughly equal to the average rate of 2.15 percent from $1963-70$, and lower than the 3.40 percent average rate of 1967-70.

One might conclude from this record that Yale does not maintain an endowment in large part, or even in significant part, to help cushion the university from the effects of financial shocks. There are, however, other circumstances that make the experience of the 1970s difficult to interpret.

\section{The Experience of the 1970s}

In the late 1960s many universities (with Yale among the vanguard) began to revise their traditionally conservative policies for endowment management in two important respects. First, they abandoned the practice of investing largely in bonds and high-dividend stocks and began to invest instead in growth stocks - that is, stocks that paid small dividends and were relatively risky but held the promise of high expected growth in market price. Second, they abandoned the practice of spending only out of cash income (that is, dividends and interest received) and adopted the "total return" approach to endowment spending, whereby some portion of capital gains is also considered part of endowment income and thus available to be realized and spent currently. These changes were spurred by a stock market in its second decade of sustained growth, by the need to finance the substantial programs of expansion on which many universities had embarked, and by the active leadership of the Ford Foundation. ${ }^{40}$

Then, just as universities suddenly started to feel other financial pressures in the early 1970s, the stock market began a decade of retreat. The real value of many university endowments fell drastically. ${ }^{41}$ This experience is reflected in column 2 of Table 2: the real value of Yale's endowment peaked in 1969; it then fell more or less continuously until 1982, when it had only 54 percent of its 1969 value. The 1970 s were therefore an unattractive time in which to liquidate a portion of the remaining capital value of university endowments in order to support operating budgets. Indeed, there seems to have been a feeling that the liberal endowment spending practices of the late 1960s were in part responsible for the difficulties in which the universities found themselves. If the universities

${ }^{40}$ See Advisory Committee on Endowment Management, supra note 21; Cary \& Bright, supra note 19.

${ }^{41}$ If we sum the endowments of the eight Ivy League schools plus Chicago and Stanford, the total, in constant (1967) dollars, drops precipitously from $\$ 3.16$ billion in 1971-72 to $\$ 2.20$ billion in 1973-74, then oscillates around roughly that level until 1979-80, when it reaches a low of $\$ 2.08$ billion, after which it increases relatively steadily, reaching $\$ 3.90$ billion in 1985-86. (Data from Council for Financial Aid to Education, Voluntary Support of Education Report.) 
had been more conservative then, they would not have become committed to such large budgets and would have had larger endowments to tide themselves over when things got bad.

Thus, the hard times of the early 1970 s seem to have reinforced an attitude of conservatism in the management of university endowments that has persisted into the present. ${ }^{42}$ The liberal endowment management strategies that became popular in the late 1960s-investment in growth stocks and a willingness to include capital gains as part of spendable endowment income-were not repudiated, and by now they have become common practice ${ }^{43}$ But, as we have seen, many universities today employ a spending formula that confines spendable endowment income to the real rate of return, thus apparently ruling out any effort to liquidate and spend a portion of the endowment's capital value.

It is possible that, if the stock market had remained firm in the 1970s, universities would have exhibited much greater willingness to spend out of endowment capital to support their badly strained operating budgets. Thus, the most we can conclude from the record is that there is little affirmative evidence that universities have viewed their endowments principally as buffers for their operating budgets, even during the severe financial crisis of recent years.

This is not to deny that endowments are used as financial buffers in a limited degree. It is apparent from Table 2, for example, that Yale has used flows to and from its endowment to smooth out its annual budget, withdrawing from the endowment on net in some years and adding to it in others. But the amount of capital that Yale, and many other universities, maintain in their endowments is far larger than necessary to manage the relatively modest transactions of this type that are undertaken from year to year.

\section{LONG-TeRM SECURITY}

It may be, however, that university endowments are maintained to serve as insurance, not against relatively short-term swings in financial conditions, but rather against the demise of the institution as a whole even when it faces adverse circumstances for long periods of time-that is, over decades, or even generations. If an ordinary business firm were to

\footnotetext{
42 Although the conventional wisdom seems to be that the decade of the 1970 s as a whole was extremely bad for higher education, it has been argued that, objectively viewed, that decade was in fact an exceptionally good one overall-perhaps the best in the nation's history except for the 1960s. See Carnegie Council on Policy Studies in Higher Education, Three Thousand Futures: The Next Twenty Years for Higher Education 10-14 (1980).

${ }^{43}$ NACUBO, 1986, supra note 19, at 2.
} 
sustain repeated losses over many years, it would probably be efficient for the firm to go out of business-and inefficient for the firm to draw on all of its retained earnings from earlier decades to cover its losses. But there might be good reasons for a university to seek to insure that it can survive even rather long periods of financial adversity.

\section{A. Preserving Reputational Capital}

To begin with, a university's alumni have an interest in having their alma mater continue to prosper long after they graduate. The survival and quality of the university serve as a continuing signal of the quality and character of its graduates; for the university to decline or disappear might affect their reputations or self-image. Further, for some alumni a university continues to be a focal point for socializing with one's fellow graduates and for making useful social and business contacts with more recent graduates.

These interests may help explain why alumni continue to contribute to a university long after they graduate. ${ }^{44}$ More to the point here, they help explain why it is that a prospective university student might prefer to attend an institution with a large endowment. The student is making a substantial commitment by choosing a given university: she is investing in a relationship that will continue to bear fruit over the rest of her life. The value of that investment will be diminished if the university should disappear, or even suffer a conspicuous decline in quality. A large endowment offers some assurance to the prospective student that the university will be long-lived. Indeed, for this reason a university's current students may have an interest in having the university pursue a fiscally conservative policy by overcharging them a bit in the present (that is, profiting from them by charging prices higher than necessary to finance the services currently provided) in order to accumulate the financial reserves necessary to guarantee that there is a high probability that the university will remain a strong institution for the rest of the students' lives. In effect, the students are buying insurance against loss of reputational capital.

One must wonder, however, whether these considerations are sufficiently strong for most university graduates to provide a justification for substantial endowment accumulation. Surely most students get the overwhelming bulk of the benefits they will ever get from their university during the years when they are actually enrolled-not after graduation when they have other sources of reputational capital more closely associated with their work and other affiliations.

\footnotetext{
44 Another interpretation of alumni giving is that it involves repayment of an implicit loan. Hansmann, The Role of Nonprofit Enterprise, supra note 22.
} 


\section{B. Preserving Tradition}

An alternative motivation for extreme fiscal conservatism in universities may derive from the special values that long life can have in an educational institution.

For one thing, a long history can give an educational institution a widespread reputation that is a valuable asset in attracting students, faculty, and funds. Furthermore, since great age is a scarce attribute among educational institutions, it can become a source of social cachet; old colleges and universities have an advantage in becoming exclusive ones. And finally, part of what many students seek when they attend college (as opposed, perhaps, to graduate school) is identification with traditionwhich may be embodied in part in an institution's physical plant, in part in its established customs, and in part in the reputations of its graduates throughout history. And tradition is in large part a product of age.

These products of age, which we shall refer to collectively as tradition, are organization specific: if a college or university were to go bankrupt and disappear, its value as a source of tradition would be lost-and the same might be largely true if it were simply merged into another institution. The founding of other institutions to absorb the demand for education would not make up for the destruction of this particular form of organization-specific capital.

Tradition, in the sense described here, is to a degree analogous to goodwill in a business firm. But there are two important differences. First, the time necessary for a university to accumulate tradition, and the time over which it earns returns, may be much longer than is characteristic of ordinary business goodwill. Thus, major expenditures to protect it during adversity may be appropriate. Second, business firms can sell equity shares to finance the maintenance of goodwill during difficult periods, while nonprofits are limited to using debt and retained earnings (endowment) for this purpose. Debt, however, is poorly adapted for financing risky investments in organization-specific capital (which by its nature provides poor security). Thus, building an endowment may be a rational way to protect tradition.

On the other hand, it is not clear that the value of tradition is so great, or the threat of its erosion through temporary financial adversity so serious, that the accumulation of very large financial reserves is necessary to protect it. It is difficult to find examples of once-prominent private educational institutions that have disappeared through financial hardship. Also, it might plausibly be argued that tradition and reputational capital in general are often best promoted and protected by current expenditures to undertake research and train distinguished graduates and to build faculty 
and facilities for future education and research, rather than by accumulating funds.

\section{InSUlation FROM OUTSIDE DEMANDS}

A large endowment may also serve to protect a university administration and faculty from the need to cater too closely to the desires of those who ultimately provide the institution's income-whether they be students, private donors, or the government.

One way in which the endowment can play this role is by serving as a financial buffer. With a large endowment, a university's administration and faculty can give expression to unpopular ideas without creating the possibility of a short-term reduction in income that will immediately threaten serious damage to the institution. If income from other sources falls, the endowment is available to take up the slack for a time. That is, the endowment prevents the university as a whole from being held hostage in the short term by any particular source of current funding.

Alternatively, an endowment can be used simply to provide a source of income to substitute, in whole or in part, for other sources of income (such as governmental support) that might bring with them unwanted pressures for conformity. That is, rather than maintaining the endowment simply as a reserve fund to be used in case other income sources are temporarily threatened, it can be built up to the point where its regular income is sufficient to provide a substantial ongoing source of support.

\section{A. The Historical Record}

Historically, there is some evidence that endowments were first established at some major universities with such aims in mind. ${ }^{45}$ Harvard, for example, received 55 percent of its income from the Massachusetts legislature between 1700 and 1800 , and Yale likewise received substantial subventions from the Connecticut legislature during this period. At that time, neither university maintained a significant endowment fund. Not surprisingly, both institutions found themselves under pressure to be attentive to the legislatures' opinions on matters of educational policy (which in the colonial period and the early years of the republic often meant religious policy), and their public funding was cut at various times when the universities resisted those pressures.

Public funding for both institutions came to an end in the first quarter of

45 The following material on Harvard and Yale is drawn from Ronald Story, The Forging of an Aristocracy (1980); and Peter D. Hall, The Organization of American Culture, 1700 1900: Private Institutions, Elites, and the Origins of American Nationality 51-53 (1984). 
the nineteenth century, evidently in considerable measure because the religious views the universities espoused fell out of favor with the public. (Both institutions were then clearly sectarian: Harvard was Unitarian, while Yale was Congregationalist.) It was at this time that Harvard and Yale began actively soliciting donations with which they built endowments, the income from which accounted for more than 40 percent of total income at both institutions by the $1840 \mathrm{~s} .{ }^{46}$ These private sources of funds were evidently successful in insulating both universities from serious public influence in their affairs for the remainder of the nineteenth century. On the other hand, both institutions fell under the strong influence of the groups that contributed to their endowments. This was particularly evident in the case of Harvard, whose administration came to be dominated by Boston's business elite. The establishment of endowments at Harvard and Yale therefore served to protect these institutions from the vicissitudes of the political process. It did not, however, free them from outside influence entirely but, rather, served to shift the source of that influence.

\section{B. Some Contrary Evidence}

Although it seems clear that Harvard and Yale originally solicited endowment funds as a replacement for public subventions, it does not necessarily follow that an important motivation was to insulate the universities from a dependence on public resources that might make them hostage to the whims of legislatures. An alternative view of the record is that private grants, including endowment funds, are simply viewed by universities as a substitute for public funds and are relied on only when, and to the extent that, public funds are unavailable. ${ }^{47}$

The latter interpretation is supported by the experience of recent decades, during which substantial public subventions have again become available to private universities. If the universities were concerned that public funding threatened their intellectual freedom, they would presumably have increased their endowments proportionately as reliance on public funding increased. Yet this has not occurred. As the proportion of university budgets accounted for by public funds has increased, the ratio of endowment to budget has decreased. Column 9 of Table 2 illustrates this fact for Yale, where the ratio decreases steadily for the three decades following the Second World War.

46 These figures are based on computations from Harvard's and Yale's annual financial reports for the period.

47 Theory and cross-national empirical evidence presented by James, supra note 5, emphasizes the substitutability of public and private funding for education and identifies some important factors influencing the extent of public support at any given time and place. 
In fact, as a crude approximation, it appears that universities have maintained the proportion between endowment size and private income (tuition and gifts) roughly constant-that is, there has been no accumulation of endowment to correspond to that portion of university income that comes from the government. Yale's accounts, for example, include separate figures for income from the federal government (including grants, contracts, and student aid) ${ }^{48}$ for years since 1964; column 2 of Table 3 gives this governmental support as a fraction of the total university budget. Column 4 of Table 3 , in turn, gives the ratio between the university's nongovernmental budget and its endowment. Comparing the latter figures with those in column 9 of Table 2 shows that the ratio of nongovernmental income to endowment remained relatively constant from 1920 (when there was essentially no income from the federal government) through the 1960s. (The ratio began to increase in the 1970 s, though much of this increase can be attributed to the poor performance of the stock market during that period; in recent years the ratio has begun to decrease again.)

\section{A Buffer against Private Donors?}

An alternative view, and one that is more consistent with the historical pattern of behavior just reviewed, is that universities have accumulated endowments, not to protect themselves from the pressures that come from the government, but rather to put them less at the mercy of the whims of private donors or even students. It is not easy to test this hypothesis from the available record. One thing that argues against it, however, is that private donors themselves seem so fond of contributing to endowment. One strongly suspects, as discussed further below, that in fact the accumulation of endowments is undertaken in substantial part in deference to the desires of donors and not as a check on those desires.

\section{The Policy Question}

In short, it is not at all clear from the evidence that universities have accumulated endowments in important part as a means of protecting institutional autonomy.

Moreover, from a normative perspective, the desirability of maintaining endowments to assure institutional autonomy is quite ambiguous. The appeal of such a policy depends on whether one thinks that more or less responsiveness to the preferences of government, donors, and students

48 This figure does not include the tax revenues forgone by the federal government as a consequence of the deductibility of private donations to the university under the personal income tax. 
who pay tuition is desirable. On the one hand, the substantial institutional autonomy that an endowment permits may help keep the maintenance of culture and the pursuit of knowledge from being blown about unduly by the shifting winds of ideology and interest; on the other hand, as Adam Smith forcefully argued, it may provide an unfortunate opportunity for irrelevance and sloth. ${ }^{49}$

\section{Subsidizing Values}

A related, but slightly different, theory is that an endowment can serve the present generation as a means of insuring that its values will be passed on to the next generation. The values in question may be broad, such as freedom of inquiry, a liberal education, or the production of useful knowledge, or they may be narrower, such as the perpetuation of a particular religious creed (Unitarianism in the case of nineteenth-century Harvard, Congregationalism in the case of Yale) or the perpetuation of the influence and mores of a commercial and social elite (both Yale and, conspicuously, Harvard in the nineteenth century). In economic terms, one might say that the present generation is seeking to subsidize value formation in the next generation. The subsidy is not needed for reasons of ability to pay since the next generation will presumably be more prosperous than the present one. Rather, the subsidy is called for only if the current generation fears that some future generation will (mistakenly) esteem the "right" values too little and will let the university that perpetuates those values go to waste if the institution is set up simply on a pay-as-you-go basis.

On the other hand, this rationale is subject to an objection similar to that described above with respect to the intergenerational transfers rationale: a university might have a stronger effect on the values of succeeding generations if its current funds were invested, not in stocks and bonds, but rather in faculty, buildings, and a great tradition of research and education. In any case, the normative appeal of this rationale of course depends on one's view of the values being subsidized.

\section{The Preferences of Donors}

The several rationales for endowment accumulation reviewed above all involve an appeal to the long-run best interests of society and, particularly, of students. That is, whether or not one finds any of these rationales convincing, they all at least seek to explain endowment accumulation as a device that might be chosen to advance social welfare in a principled way. We turn now to several behavioral explanations for endowment accumu-

49 Adam Smith, 2 The Wealth of Nations 282-302 (E. Cannan ed. 1976). 
lation that involve no such social welfare argument but, rather, suggest that endowments may be at least in part a consequence of self-interested or short-sighted action by the individuals who support or manage universities.

To begin with, it is a truism that many donors restrict their gifts for use as endowment, not to advance education and knowledge, but to purchase a bit of personal immortality. Moreover, it is possible that universities maintain substantial amounts of quasi endowment in part to appeal to the same instincts that lead donors to restrict their gifts to true endowment. For instance, some individuals, though prepared to leave their gifts unrestricted (or unprepared to undertake the formalities necessary to restrict their gifts to endowment), may nevertheless be more willing to donate if they believe that their gifts will be used for endowment or other capital projects rather than being spent currently. By annually adding some fraction of its unrestricted gift income to endowment rather than spending all such income currently, a university can induce in donors some faith that this belief is justified. If a university were to limit its endowment to funds that are legally restricted to such use, it might receive fewer gifts in total, and more that are formally restricted. ${ }^{50}$ In short, it may be that universities accumulate not just true endowment but also quasi endowment, at least in part because that is simply an effective way to raise funds.

As a normative matter, respecting the wishes of donors does not in general threaten efficiency. Others might prefer that donors spend their money differently, but it is, after all, the donors' money. If we respect an individual's right to spend his money as he wishes, in general, we should also respect his decision to designate the purposes for which his gifts will be used-at least so long as the recipients are agreeable as well. There is, however, a potential inefficiency associated with restrictions on the use of property, including invested funds, that extend beyond the life of the donor. Over time, the donor's purposes may become much less valuable than they appeared during the donor's lifetime, so that the donor, if he were alive, would himself prefer, or could be persuaded or bargained with, to divert the funds to another object. But, since the donor is no longer around, the funds will remain locked into their original purpose. ${ }^{51}$

\footnotetext{
${ }^{50}$ One might think that a large endowment-and particularly a large accumulation of unrestricted funds-would tend to discourage further donations since potential donors might conclude that the university is already sufficiently prosperous. The reverse, however, is sometimes argued: donors wish to participate in a permanent and conspicuously successful venture-to help build a monument, even if it is only a hoard of negotiable securities; thus, paradoxically, they are less likely to contribute to a university if it appears pressed for funds.

${ }^{51}$ Or, put differently, one cannot bargain over the allocation of property rights when those rights belong to a dead person. Thus, the Coase Theorem does not apply here; the rule of law matters, from the standpoint of efficiency, when it comes to restrictions that outlive
} 
If perpetual restrictions on the use of property were generally honored by the law, there would thus be a tendency for an ever larger portion of society's wealth to become trapped into outmoded uses. And it is the preferences of the ignorant and short-sighted that would be most honored in the long run.

It is presumably for these reasons that perpetual restrictions are generally unenforceable in law. ${ }^{52}$ Only gifts to charity are exempt, presumably because charitable purposes are, by definition, considered generally beneficial to society, and because there is an escape hatch in the doctrine of cy pres, which allows courts to divert funds from their original purposes if those purposes become clearly impracticable. Because, however, the legal definition of charitable purposes is extremely broad, the doctrine of cy pres is narrow, and the few individuals who have standing to bring a cy pres action (the trustees and the attorney general) ${ }^{53}$ have little incentive to do so, there arguably remains substantial opportunity for donors to restrict gifts to educational institutions in ways that prove, over time, quite inefficient.

In any event, endowment accumulation by nonprofits seems in many cases to go well beyond the desires of donors. This is quite apparent in the case of some types of nonprofit institutions other than universities. For example, although very few of the large private foundations in the United States received their funds as true endowment, burdened by their founding donor with a restriction on expenditure of capital, most have chosen to treat their funds as if they had. ${ }^{54}$ Since these institutions have already received the one and only donation they will ever get, such behavior can no more be ascribed to encouragement of further gifts than to compliance with the intentions of the founder. Such examples suggest that the personal preferences or perspectives of those who manage the institutions in question may be at least in part responsible for endowment policy.

To be sure, it has been argued that the investment decisions of nonprofits will necessarily reflect the preferences of donors for present versus future consumption since donors have the option of contributing either

the owner of the property. See Robert C. Ellickson, Adverse Possession and Perpetuities Law: Two Dents in the Libertarian Model of Property Rights, 64 Wash. U. L. Q. 723, 73437 (1986).

52 Not all would agree, however, that the existing restrictions on perpetual conditions are either necessary or effective in preventing undesirable restraints on alienation. See Richard Epstein, Past and Future: The Temporal Dimension in the Law of Property, 64 Wash. U. L. Q. 667, 710-16 (1986).

${ }^{53}$ See Bogert, supra note 18.

54 John Simon, The Tax Treatment of Nonprofit Organizations: A Review of Federal and State Policies, in Powell, ed., supra note 5, at 67, 80 n.24. 
currently or in the future, or of not contributing at all (or contributing to another institution), and thus can constrain the choices made by those who manage nonprofits. More particularly, it has been argued that nonprofits will make investments that reflect the trade-off between present and future returns that is available in the capital markets since donors have the option of making a contribution currently or investing in the capital markets and donating later. ${ }^{55}$

This argument has some plausibility to the extent that it predicts that donors will succeed in keeping nonprofits from spending to much currently and saving too little: to prevent that, donors can always delay donation or restrict their donation for use as endowment. But it is not convincing as a limitation on the ability of nonprofits to save more than donors would prefer. For the argument to work in that case, one must assume, among other things, that the nonprofit involved has no market power in the market for donations, which is in general implausible. When, for example, Harvard solicits contributions from Harvard graduates, they are unlikely to feel that a contribution to Yale is a perfect substitute, and thus they are unlikely to refuse to contribute to Harvard altogether simply because they feel that Harvard is accumulating too much of its income and spending too little currently.

A donor can, of course, make a contribution subject to the restriction that it be spent currently, but that would generally be a meaningless restriction since the institution can simply retain other funds in its place. And to write an enforceable contract sufficient to prevent such substitution in a large and financially complex institution such as a university would in most cases be infeasible.

Consequently, those who manage nonprofits presumably have some discretion concerning their institutions' saving behavior, and their incentives deserve scrutiny.

\section{Preferences of Administrators and Faculty}

Extreme fiscal conservatism may serve the personal interests of a university's faculty and administrators. These individuals have an important degree of control over a university. That control is not, however, accompanied by all the incidents of full ownership; in particular, faculty and staff do not have the right to appropriate directly the institution's net earnings. There are, however, indirect ways in which to extract profits. One, of course, is through perquisites, such as a light work load, a pleas-

\footnotetext{
${ }^{55}$ Eugene F. Fama \& Michael C. Jensen, Organizational Forms and Investment Decisions, 14 J. Fin. Econ. 101, 115-17 (1985).
} 
ant physical environment, or interesting students. Another is by purchasing job security. Faculty and administrators, when faced with a trade-off between using current surpluses to increase the present level of services or, alternatively, to build reserves that will help make their jobs secure in the future, may well be inclined toward the latter; the former course will benefit primarily the students and the new faculty who are hired for the expanded programs, while the latter course will have benefits more closely confined to the current faculty alone. This is not to suggest that faculty and administrators self-consciously seek to exploit their universities through the manipulation of endowment policy. It is simply to note that the importance of stability and continuity in the life of an educational institution may have unusual salience to its employees.

Other types of large nonprofit corporations have shown such a tendency toward excessive accumulation of assets. For example, there is strong evidence that nonprofit hospitals have been substantially overcapitalized in recent years. ${ }^{56}$ Mutual insurance companies,${ }^{57}$ in turn, have systematically tended to build up, through retained profits, financial reserves well in excess of those necessary to serve their current policyholders. ${ }^{58}$ And, of course, there are some famous historical precedents as well: the substantial accumulated wealth of Buddhist monasteries in T'ang Dynasty China (in the year 845), and of Christian monasteries in sixteenth-century England, was expropriated by the state in part, at least, out of a feeling that this wealth had become excessive relative to the services that the monasteries provided to society. ${ }^{59}$

Even for-profit firms may exhibit such behavior. For example, it has been argued that the relatively low debt-equity ratios that have characterized widely held U.S. business corporations reflect, in part, the desire of corporate managers to pursue the survival of their corporations and their careers, even at the expense of profitability, by creating job security for

${ }^{56}$ See the findings reported in Senate Report No. 93-1285, reprinted in 1974 U.S. Code Congressional and Administrative News, at 7842, 7878-79; Senate Report No. 96-96, reprinted in 1979 U.S. Code Congressional and Administrative News, at 1306, 1358.

57 Mutual insurance companies are not, strictly speaking, nonprofit firms but, rather, are a variety of consumer cooperative. Yet, since they first appeared in the $1840 \mathrm{~s}$, they have operated like pure managerial or "entrepreneurial" nonprofits over which the patrons (policyholders) exercise no meaningful control. See Henry Hansmann, The Organization of Insurance Companies: Mutual versus Stock, 1 J. L. Econ., \& Org. 125 (1985).

58 John Hetherington, Fact v. Fiction: Who Owns Mutual Insurance Companies? 1969 Wisc. L. Rev. 1068.

59 Kenneth Ch'en, The Economic Background of the Hui-ch'ang Suppression of Buddhism, 19 Harv. J. Asiatic Stud. 67 (1956); J. D. Mackie, The Early Tudors, 1485-1558, at 370-79, 396-401 (1952). 
themselves through excessive accumulation of capital that can provide a substantial cushion against misfortune. ${ }^{60}$

On the other hand, endowment accumulation at major universities seems to exceed substantially that which could reasonably serve the security interests of present faculty, whose time horizon in this respectdetermined by the time they can expect to remain in their current university's employ-is on average probably no more than about twenty years. Casual empiricism, moreover, suggests that university faculty are far from unanimous in supporting conservative endowment policies, often preferring instead an increase in spending on current programs.

\section{XiII. The Peculiar Perspective of Trustees}

A further explanation for endowment accumulation may lie in the particular perspective that university trustees bring to their office.

The trustees of universities, who generally come from the business world rather than the academic world, are often in a poor position to exercise meaningful oversight over the actual operations of the institution. The management of the endowment, on the other hand, is closer to their areas of professional expertise. This may help explain the pattern that is commonly observed-namely, that the trustees tend to focus a disproportionate amount of their attention on the endowment and make its preservation or growth a special priority. This tendency may be reinforced by the fact that the size and growth of the endowment is a tangible and easily measured thing, whereas many of a university's other objectives are more difficult to define and much less immediately observable, making the university's success in meeting those objectives harder to measure. Furthermore, in the business world, dollar figures are used as a measure of the success of an institution. It may be that, consciously or unconsciously, university trustees tend to focus on the size of the university's retained earnings (that is, its endowment) as a measure of the success of the management of the institution. Indeed, rather than simply viewing the endowment as a potential means for improving the university's output of education and research, to some extent trustees may, conversely, tend to view the university's academic activities as a constraint on, or a means to, the autonomous objective of having a large and growing endowment. In this vein, one sometimes has the sense that universities compete among themselves to have the largest endowment, as if

\footnotetext{
${ }^{60}$ See, for example, Gordon Donaldson \& Jay Lorsch, Decision Making at the Top: The Shaping of Strategic Direction (1983).
} 
accumulating a large endowment were in itself an important measure of institutional success. And it is a form of competition that has a Veblenian appearance, as if the universities were engaging in conspicuous consumption (or, what is the same thing here, conspicuous nonproduction) - since an endowment, in a sense, represents accumulated income that the university has been able to afford not to spend on education and research.

Some evidence that the maintenance of an endowment is often viewed as an objective in its own right, rather than simply as a means to an end, comes from the infrequency with which endowment policy seems to be connected even to a university's other investment programs. For example, it would seem logical for a university to compare the return it can get on the securities in its endowment with the return it can get, in terms of both services and reduced future expenditures, from investment in its own physical plant and then seek to allocate funds between endowment and physical plant in a fashion that equates these returns at the margin. Yet endowment policy is rarely discussed in these terms. ${ }^{61}$

In any event, whether or not trustees' concern with endowment accumulation goes to the extreme of making the size of the endowment an end in itself, it is frequently observed that they seem exceptionally risk averse in their approach to university finances. Perhaps the reason for this is that, for the reasons of expertise mentioned above, they feel themselves likely to take the blame if the institution fails financially, while others are likely to get the credit if it succeeds academically. Consequently, large financial reserves are a source of substantial comfort to them.

Such a tendency toward extreme financial conservatism, or even making the endowment an end in itself, may be reinforced by the fact that the members of the board of directors of many nonprofit corporations, including universities, are commonly referred to as "trustees." In fact, they are not trustees in the strict sense. In particular, they are not, as the term might suggest in this context, trustees of a charitable trust and bound by the rules that govern such trustees. Rather, their role and their obligations are in most respects similar to those of the members of the board of directors of a business corporation, ${ }^{62}$ and they could-and perhaps should-simply be termed "directors" rather than "trustees."

61 Fama \& Jensen, supra note 55, at 116 reason (a priori) that "the opportunity costs signalled by endowment portfolio investments lead the internal agents of non-profits to evaluate cost saving capital projects according to the same maximum wealth or market value rule which is optimal for [business] corporations." But there is little evidence that this theoretical conclusion is reflected in actual practice.

62 See Stern v. Lucy Webb Hayes National Training School for Deaconesses and Missionaries, 381 F. Supp. 1003 (D.D.C. 1974); American Bar Association, Revised Model Nonprofit Corporation Act $\$ 8.30(e)$ (1987). 
Nevertheless, the term "trustee" has become conventional for the members of university boards of directors. And the term may itself have some influence on the behavior of these boards. For the term "trustee" is generally applied to individuals who are entrusted to look after a fund of money - and often a fund of money that is subject to restrictions limiting the amount of the principal, if any, that may be spent currently. Thus, if a university trustee asks herself what she is a "trustee" of, she might naturally conclude that, whatever else is involved, she is a trustee of the endowment fund and that it follows that she has a special responsibility to make certain that the fund is retained intact.

\section{Custom and Habit}

Finally, it is possible that universities seek to build or maintain endowments in considerable part simply out of custom, habit, or tradition. Having built large endowments in the nineteenth century-originally, perhaps, because donations were needed to replace lost government funds, because donors preferred giving in the form of endowment, and because the lumpy character of donations made spending them over a prolonged period rational in any event-the older universities may simply have become accustomed to having them and may be perpetuating the practice of maintaining or increasing them largely as a tradition that merely lingers on without a well thought-out modern rationale. And younger universities, in turn, may tend simply to adopt endowment policies that mimic those of the older and more illustrious institutions.

\section{Conclusion}

The argument that has been offered most frequently in recent years to explain the accumulation of endowments-that they are a means to intergenerational equity -is unpersuasive. More compelling reasons to accumulate endowments are that they serve as a financial buffer against periods of financial adversity, that they help to insure the long-run survival of the institution's reputational capital, that they protect the institution's intellectual freedom, and that they assist in passing on values prized by the present generation. It is not clear, however, that these are today the reasons why endowments are accumulated. Nor is it clear that the sizes of existing endowments, and the ways in which they are managed, are well chosen to serve these goals. In particular, prevailing endowment spending rules seem inconsistent with most of these objectives.

We cannot say, from the arguments and evidence surveyed here, that the endowments of the major private universities today are either too big or too small. It does appear, however, that surprisingly little thought has 
been devoted to the purposes for which endowments are maintained and that, as a consequence, their rate of accumulation and the pattern of spending from their income have been managed without much attention to the ultimate objectives of the institutions that hold them.

Given the poor state of our understanding, it would be premature to propose changes in the law governing endowment accumulation and, in particular, to propose measures to limit the discretion of universities to accumulate large endowments. Moreover, the importance of adopting such restrictions is lessened by the fact that even substantially excessive endowment building may lead to only a limited amount of waste from a social welfare standpoint. Because funds that a university devotes to endowment are today typically invested in market securities, they are at least being used productively. ${ }^{63}$ Indeed, efforts to limit endowment accumulation might in part have the effect of diverting universities toward other, less efficient forms of accumulation (for example, useless facilities or excessive esoteric research by faculty) or toward unproductive current spending.

Nevertheless, there are costs associated with excessive endowment accumulation; funds may be diverted from more productive uses either within or without the institution. The mere potential to adopt legislation restricting endowment accumulation-made more salient by the recent enactment of such legislation in other countries and by the enactment in this country of restrictions on accumulation by private foundations-may therefore be a useful stimulus to universities and other endowed institutions to satisfy themselves and others that their policies toward endowment accumulation are reasonable in light of the ends to which their institutions are dedicated.

\section{APPENDIX}

\section{Intergenerational Wealth Transfers through Endowment Accumulation}

To understand the intergenerational efficiency of alternative endowment spending rules, it helps to consider some simple models.

No Future Gifts, Zero Discount Rate. To begin with, let us ignore externalities, such as the social benefits of university research, and assume that the university's objective is simply to maximize the undiscounted sum of utilities of all future generations of students at the university (that is, we shall assume a zero

${ }^{63}$ This is in contrast, for example, to the situation with the Buddhist monasteries in T'ang Dynasty China, which accumulated a large fraction the nation's valuable metals (often in the form of images), thus removing them from the economy and creating a strong incentive for expropriation by the state. See Ch'en, supra note 59. 
rate of time discount). Let us also assume that the size of the university's student body remains constant, that the amount of education consumed by each generation of students remains constant, and that there is no risk. Then the utility enjoyed by a given generation of students will just be a function of their aftertuition income, and we can represent the utility of a typical student in year $t$ as

$$
U_{t}=U\left(Y_{t}-C_{t}+S_{t}\right),
$$

where $Y_{t}$ is the student's income at time $t, C_{t}$ is the cost to the university of educating a student, and $S_{t}$ is the per-student subsidy from the endowment. (It might, in fact, be most sensible here to consider $Y_{t}$ as reflecting the student's parents' income or the present value of the student's future income.) Take the simple case in which the endowment per student has an initial value at time 0 of $E_{0}$, to which no further gifts are added. Assume that real student income grows at an exponential rate of $g$, that real costs increase at the rate $c$, and that the real rate of return on the endowment is $r$.

Will intergenerational equity be maximized by spending an equal amountnamely, $r E_{0}$, the real return on the endowment-each period? With such a policy, we can rewrite (1) as

$$
U_{t}=U\left(Y_{0} \mathrm{e}^{g t}-C_{0} \mathrm{e}^{c t}+r E_{0}\right) .
$$

This will maximize total utility only if reducing (or increasing) endowment spending by an amount $Q$ in one period (say, period 0 ) and spending the resulting increase (or decrease) in accumulated endowment, $Q \mathrm{e}^{r t}$, in a later period $t$ will not increase total utility. That is, total utility will be maximized with equal spending out of endowment in each period only if

$$
\frac{d}{d Q}\left[U\left(Y_{0}-C_{0}+r E_{0}-Q\right)+U\left(Y_{0} \mathrm{e}^{g t}-C_{0} \mathrm{e}^{c t}+r E_{0}+Q \mathrm{e}^{r \eta}\right)\right]=0
$$

for all $t$, where the derivative is evaluated at $Q=0$. Assuming, for illustration, a logarithmic utility function, (3) is equivalent to

$$
Y_{0}\left(\mathrm{e}^{r t}-\mathrm{e}^{g t}\right)-C_{0}\left(\mathrm{e}^{r t}-\mathrm{e}^{c t}\right)+r E_{0}\left(\mathrm{e}^{r t}-1\right)=0 .
$$

So long as the parameters $Y_{0}, C_{0}, E_{0}$, and $r$ all take positive values, there are no values of the parameters for which this condition is met for all values of $t$ and, thus, no circumstances under which the currently conventional rule calling for spending annually the real return on existing endowment is appropriate in this model. (Viewed as a function of $t$, the left-hand side of [4] has only a finite number of roots for any given set of positive values for the parameters, and hence there are at most a finite number of values of $t$ for which [4] is satisfied.) Rather, if the left-hand side of (4) is negative, as might be the case if $r$ is roughly equal to $g$ and if $c$ is much smaller than $r$, then an endowment spending rule that calls for a higher rate of current expenditure is appropriate, and the converse is true if the left-hand side of (4) is positive, as might be the case if $r$ is substantially larger than $g$ but roughly equal to $c$.

A More General Model. Let us generalize the model above by dropping the restrictive assumption that the rate of discount is zero and, instead, introducing a discount rate of $i$. Also, let us take into account the gift income $G_{t}$ that is expected 
in each future year $t$. In particular, let us assume that gift income is expected to grow at a rate $s$, so that $G_{t}=G_{0} \mathrm{e}^{s t}$. Then the left-hand side of (3) becomes

$$
\begin{aligned}
\frac{d}{d Q}[ & {\left[U\left(Y_{0}-C_{0}+r E_{0}+G_{0}-Q\right)\right.} \\
& \left.+\mathrm{e}^{-i t} U\left(Y_{0} \mathrm{e}^{g t}-C_{0} \mathrm{e}^{c t}+r E_{0}+G_{0} \mathrm{e}^{v t}+Q \mathrm{e}^{r t}\right)\right] .
\end{aligned}
$$

Again using a logarithmic utility function, the sign of (5) will be the same as the sign of

$Y_{0}\left[\mathrm{e}^{(r-i) t}-\mathrm{e}^{g t}\right]-C_{0}\left[\mathrm{e}^{(r-i) t}-\mathrm{e}^{c t}\right]+r E_{0}\left[\mathrm{e}^{(r-i) t}-1\right]+G_{0}\left[\mathrm{e}^{(r-i) t}-\mathrm{e}^{v t}\right]$.

Only if the value of (6) is positive would welfare be enhanced by adding a portion of gift income to endowment rather than spending it all currently. As in the case of (4), (6) could in fact be positive or negative, depending on the particular values taken by the parameters. It will tend to be positive if $i$ is small relative to $r$ and if $c$ is large relative to $v$ and $g$, and it will tend to be negative in the reverse circumstances. 